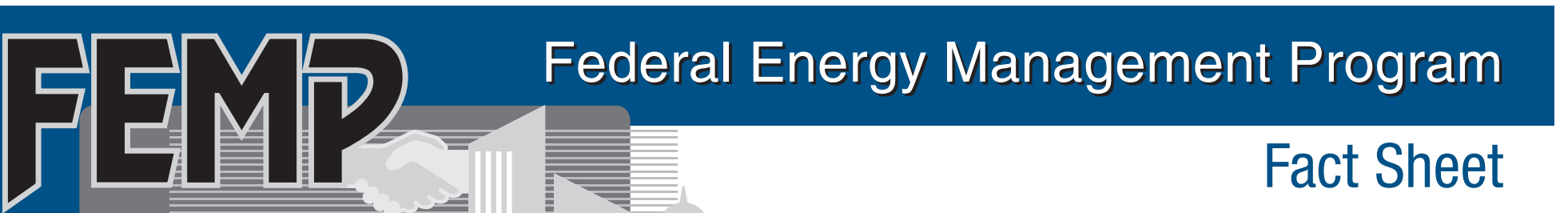

Leading by example, saving energy and taxpayer dollars in federal facilities

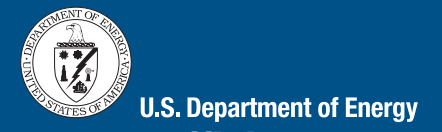
Energy Efficiency and Renewable Energy Bringing you a prosperous future where energy is clean, abundant, reliable, and affordable

\title{
Invest in UESCs today to meet your energy efficiency goals!
}

Utility Energy Services Contracts (UESCs) bring Federal agencies and utilities together to identify, develop, finance, and implement cost-effective energy efficiency, water conservation, and renewable projects at Federal sites.

\section{What is a UESC?}

Through the use of UESCs, participating utility companies agree to provide Federal agencies with services or products (or both) that are designed to increase the energy efficiency of Federal facilities. UESCs can also serve as a project financing tool for Federal facilities. During the contract period, the facility pays a lower utility bill plus a payment to the utility for the UESC. The total of the two payments may be less than or equal to an average utility bill before activating the UESC. Although projects are not required to reduce the government's costs during the contract period, they often do. Following the completion of a project, the utility bill will be reduced as a result of increased energy and water efficiency.

\section{What are the benefits of UESCs?}

UESCs offer many benefits to a Federal agency, including:

- Streamlined procurement process

- Flexible contracts

- Rebates and incentives
- Relationship with a long-standing entity

- Payment through the utility bill

- Flexibility in measurement and verification

- One-stop-shopping for a turnkey project

- Water savings can be included in projects

Agencies can capitalize on the many advantages UESCs offer. For example, UESCs enable Federal agencies to implement energy efficiency projects without using direct appropriations (however, UESCs can also be used in conjunction with appropriations). Contracting vehicles such as area-wide contracts, basic ordering agreements, and other agreements used in UESCs save time in implementing site-specific projects. This type of contracting allows agencies greater flexibility in developing energy conservation, water conservation, and renewable energy projects, which in turn help agencies in meeting their EPACT 2005 and EO 13423 goals.

FEMP provides direct assistance to agencies striving to implement UESC projects at Federal facilities. Direct assistance is designed to provide guidance and best practices, training, direct technical assistance and partnership building to agencies and utilities working through the UESC process. At an agency's request, FEMP project facilitators can help the agency implement sensible, cost-effective, and comprehensive projects that provide the best 
value to the government. Direct assistance

is designed around these guiding principles:

- Provide technical tools and resources

to agencies and utilities navigating the

UESC process

- Gain project team commitment to

increase the quality and quantity of UESC

projects

- Describe and simplify the process of

UESCs and other utility services and

financing options

For more information, go to: http://www1.eere. energy.gov/femp/financing/uescs.html
A Strong Energy Portfolio for a

Strong America

Energy efficiency and clean, renewable energy will mean a stronger economy, cleaner environment, and greater energy independence for America. Working with a wide array of state, community, industry, and university partners, the U.S. Department of Energy's Office of Energy Efficiency and Renewable Energy invests in a diverse portfolio of energy technologies.

\section{For More Information}

David McAndrew, UESC Project

Manager

DOE/FEMP

202-586-7722

david.mcandrew@ee.doe.gov

Karen Thomas, Senior Project Leader, UESC Lead

National Renewable Energy Laboratory 202-646-5223

karen_thomas@nrel.gov

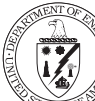

\section{Energy Efficiency} and Renewable Energy

Bringing you a prosperous future where energy is clean, abundant, reliable, and affordable

EERE Information Center

1-877-EERE-INF or 1-877-337-3463

www.eere.energy.gov/

Produced for the U.S. Department of

Energy by the National Renewable Energy

Laboratory, a DOE national laboratory.

DOE/GO-102007-2455

August 2007 